OPEN ACCESS

Edited by:

Adi Avni,

Tel Aviv University, Israel

Reviewed by:

Rosa Rao,

University of Naples Federico II, Italy

Maya Bar,

Agricultural Research Organization

(ARO), Israel

${ }^{*}$ Correspondence:

Federico Brilli

federico.brilli@ipsp.cnr.it

Ivan Baccelli

ivan.baccelli@ipsp.cnr.it

Specialty section: This article was submitted to Plant Microbe Interactions, a section of the journal

Frontiers in Plant Science

Received: 12 November 2018 Accepted: 19 February 2019

Published: 19 March 2019

Citation:

Brilli F, Loreto F and Baccelli I (2019)

Exploiting Plant Volatile Organic

Compounds (VOCs) in Agriculture to

Improve Sustainable Defense

Strategies and Productivity of Crops.

Front. Plant Sci. 10:264.

doi: 10.3389/fp/s.2019.00264

\section{Exploiting Plant Volatile Organic Compounds (VOCs) in Agriculture to Improve Sustainable Defense Strategies and Productivity of Crops}

\author{
Federico Brillit ${ }^{1 *}$, Francesco Loreto ${ }^{2}$ and Ivan Baccelli ${ }^{1 *}$ \\ ${ }^{1}$ Institute for Sustainable Plant Protection, National Research Council of Italy, Florence, Italy, ${ }^{2}$ Department of Biology, \\ Agriculture and Food Sciences, National Research Council of Italy, Rome, Italy
}

There is an urgent need for new sustainable solutions to support agriculture in facing current environmental challenges. In particular, intensification of productivity and food security needs require sustainable exploitation of natural resources and metabolites. Here, we bring the attention to the agronomic potential of volatile organic compounds (VOCs) emitted from leaves, as a natural and eco-friendly solution to defend plants from stresses and to enhance crop production. To date, application of VOCs is often limited to fight herbivores. Here we argue that potential applications of VOCs are much wider, as they can also protect from pathogens and environmental stresses. VOCs prime plant's defense mechanisms for an enhanced resistance/tolerance to the upcoming stress, quench reactive oxygen species (ROS), have potent antimicrobial as well as allelopathic effects, and might be important in regulating plant growth, development, and senescence through interactions with plant hormones. Current limits and drawbacks that may hamper the use of VOCs in open field are analyzed, and solutions for a better exploitation of VOCs in future sustainable agriculture are envisioned.

Keywords: volatile organic compounds, defense priming, abiotic and biotic stresses, sustainable crop production, smart agriculture

\section{IS CONVENTIONAL AGRICULTURE READY FOR A NEW CHALLENGE?}

Reports analyzing the status of agriculture worldwide forewarn that a significant increase of the present agricultural production would be necessary to meet the future demand for food, as the world population is expected to rise from 7.3 to 9.7 billion by 2050. As a consequence, FAO recently projected that an increase of food production (70\%) may be required and thus a third green revolution needs to be attained (FAO, 2017). Enhanced crop yields in the past 50 years were made possible by the introduction of mechanization, the progresses in genetics and the use of improved crop varieties, as well as the extensive use of chemicals such as fertilizers and pesticides. However, the yield of grain crops considered the main sources of human and livestock calories (e.g., rice) have already reached a "plateau" (Grassini et al., 2013). Natural resources providing fertilizers (especially phosphate, Peñuelas et al., 2013) are also depleting, and the use of chemicals has caused serious problems with food safety and environmental 
pollution (Conley et al., 2009). Moreover, climate change is forecasted to increase the severity and frequency of drought events (IPCC, 2014) that will cause both a reduction in plant primary production (Zhao and Running, 2009) and a future progressive exposure of agricultural soils to degradation and loss of fertility (Köberl et al., 2011). Climate change will also favor the spreading of plant pathogens into larger geographical areas where new hosts may be found (Baker et al., 2000), leading to more frequent epidemics (Anderson et al., 2004). In this context, agriculture is called to provide solutions to increase yields while preserving natural resources and the environment.

This perspective article explores the potential of natural Volatile Organic Compounds (VOCs) emitted by plants as an eco-sustainable strategy to implement future smart agricultural practices and enhance plant protection and productivity. As airborne signals, VOCs allow quick defense signaling between distant plant organs (Heil and Silva Bueno, 2007) and the communication between plants (Baldwin et al., 2006). In addition, VOCs can "prime" the defense system of plants for an enhanced resistance to an upcoming stress (Conrath et al., 2002). However, to date, VOCs have been mostly applied in the field to repel herbivores or to attract herbivores' parasitoids or predators (De Moraes et al., 1998; Dicke and Baldwin, 2010).

\section{VOLATILE ORGANIC COMPOUNDS (VOCs) CAN BE A NATURAL AND ECO-FRIENDLY SOLUTION TO ENHANCE BOTH CROP DEFENSE AND PRODUCTION}

\section{VOCs Protect and "Prime" Plants to Withstand Biotic and Abiotic Stresses}

Emission of VOCs can be induced at any time from leaves of all plant species following abiotic (Loreto et al., 2006; Loreto and Schnitzler, 2010) or biotic stresses (Dicke and Baldwin, 2010). Results from many studies have demonstrated that emission of isoprenoids, the most abundant group of VOCs (Guenther et al., 2006), is stimulated by abiotic stresses and improves plant resistance either by direct quenching of reactive oxygen species (ROS) (Loreto and Velikova, 2001), or indirectly by stabilizing cell membranes (Velikova et al., 2011). However, protection of cell membranes to avoid toxic accumulation of ROS is only one among the many roles of VOCs that may be exploited in agriculture (Figure 1).

Plants maintain memory of any stress event they have experienced (Crisp et al., 2016; Hilker et al., 2016), and this memory is able to influence the response to forthcoming stressful situations. Factors able to shape the plant's stress memory are referred to as "priming stimuli", among which plant VOCs play a crucial role because, due to their volatility, they can quickly reach distant plant parts (Heil and Kost, 2006; Mauch-Mani et al., 2017). A "primed" plant shows an earlier, stronger, and faster response upon further stress occurrence, thereby resulting in increased resistance and/or tolerance (Conrath et al., 2015; Mauch-Mani et al., 2017).
VOCs have been extensively demonstrated to prime defenses against herbivorous insects (Kim and Felton, 2013), pathogens (Ameye et al., 2015), and environmental stresses (Cofer et al., 2018). Defense priming against pathogens has also been considered as a sort of "green vaccination" (Luna-Diez, 2016). Green leaf volatiles (GLVs) such as Z-3-hexenyl acetate, ubiquitously and rapidly released after mechanical damage of leaf tissues (Brilli et al., 2011), have been reported to prime resistance of wheat plants to the fungal pathogen F. graminearum (Ameye et al., 2015) and to reduce the damage occurring to maize plants during cold stress (Cofer et al., 2018). Other VOCs such as methyl salicylate (MeSA) and monoterpenes (i.e., camphene and pinene) (Riedlmeier et al., 2017) have been found to actively participate in the mechanisms leading to systemic acquired resistance (SAR) (Dempsey and Klessig, 2012). Low concentrations of methyl jasmonate (MeJA) have been demonstrated to prime plant defenses by modifying the epigenetic status of wound-inducible genes in rice, thereby enhancing responsiveness to wounding (Bertini et al., 2018). Even methanol, ubiquitously emitted from plant leaves during cell division and cell wall expansion (Nemecek-Marshall et al., 1995), seems to act as a priming stimulus when released from damaged tobacco leaves by enhancing resistance to the pathogenic bacterium Ralstonia solanacearum (Dorokhov et al., 2012). In addition, antibacterial defenses have also been reported to be primed by VOCs such as nonanal in lima bean plants treated with benzothiadiazole (BTH), a synthetic salicylic acid analog (Yi et al., 2009). Compared to the direct induction of defenses in plants, priming does not incur in an energetically costly activation of metabolic pathways (van Hulten et al., 2006; Martinez-Medina et al., 2016) and therefore represents a sustainable method to develop novel crop protection strategies.

\section{VOCs Inhibit Growth and Development of Plant Pathogens}

A number of experimental trials have shown the capacity of various VOCs produced by leaves to inhibit germination and growth of plant pathogens, yet the mechanisms of action remain unknown. Citral, carvacrol, and trans-2-hexenal were reported to be effective in hampering in vitro growth and germination of Monilinia laxa, the agent of brown rot of stone fruit (Neri et al., 2007). In particular, trans-2-hexenal provided protection also when tested in vivo on apricot, nectarine, and peach fruits as a postharvest biofumigant (Neri et al., 2007). In addition, the growth of Colletotrichum acutatum, causing citrus post-bloom fruit drop, was moderately inhibited in vitro when exposed to linalool (Marques et al., 2014). Botrytis cinerea, a necrotrophic fungus with a very broad host range, has been reported to be highly sensitive to the in vitro application of monoterpenes, such as (+)-limonene (Simas et al., 2017). However, exposure to $(+)$-limonene stimulated in vitro growth of the fungal pathogen Penicillium digitatum, whereas this fungus was highly inhibited by the application of citral (Simas et al., 2017). In a recent work, Quintana-Rodriguez et al. (2018) performed a screening on the efficacy of 22 different VOCs, known to be emitted from leaves, against the fungal pathogens Colletotrichum lindemuthianum, Fusarium oxysporum, and B. cinerea. These 


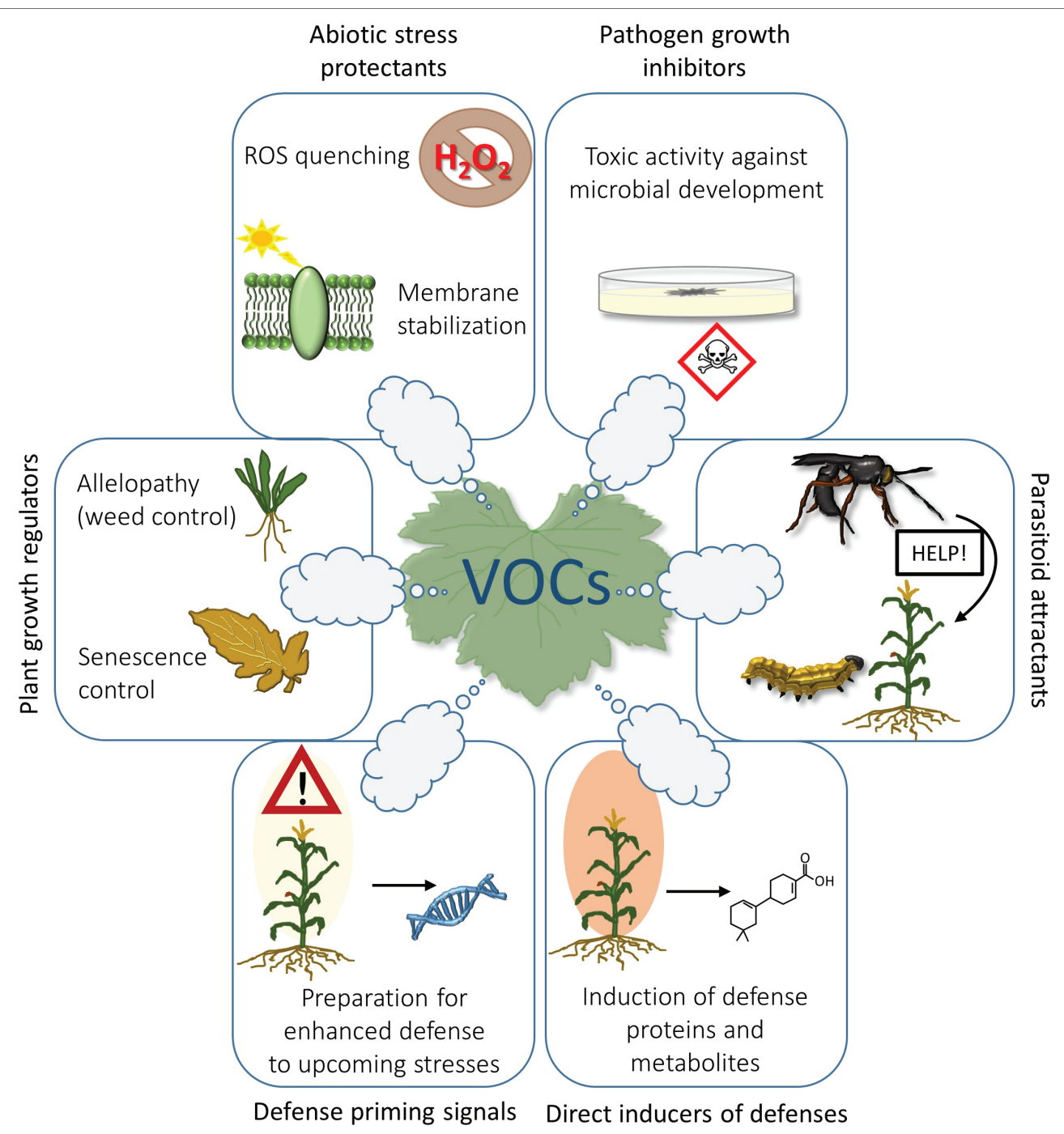

FIGURE 1 | Possible applications of plant VOCs in agriculture: isoprenoids emitted by leaves can exert a protective effect against abiotic stressors by quenching ROS or by strengthening the cell membranes; some VOCs are able to inhibit germination and growth of plant pathogens in vitro; herbivore repellency and attraction of herbivore's parasitoids on infested plants are probably the most known capacity of VOCs; VOCs can impact on plant defensive system by inducing the synthesis of defense proteins and metabolites (e.g., phytoalexins) that impair microbial colonization; VOCs can also act as priming stimuli by inducing epigenetic changes and accumulation of transcription factors that may facilitate faster expression of plant defenses (a DNA helix is thus shown in the figure), thereby enhancing tolerance or resistance to a future stress episode; VOCs can interact with the mechanism of senescence, or be exploited to fight against unwanted weed species (allelopathic effects).

fungi were grown in Petri dishes in which the headspace had been enriched, each time, with a single VOC. Results showed that exposure to nonanal, (+)-carvone, citral, trans-2-decenal, $L$-linalool, nerolidol, or eugenol significantly inhibited the growth of all these three fungal species, with eugenol demonstrating the strongest activity. Other VOCs such as cuminaldehyde and p-cymene have been also demonstrated to possess antifungal activity against B. cinerea, F. oxysporum, Verticillium dahliae, and Alternaria mali (Sekine et al., 2007).

\section{VOCs Improve Plant Growth and Productivity}

Limited information exists concerning the effects of plant VOCs on crop productivity. Emission of VOCs from leaves can have allelopathic effects and impair the growth of other competitive plant species (Arimura et al., 2010). Hexenal (Gardener et al., 1990) and isoprenoids (mono- and sesqui-terpenes) (Fischer, 1986), for instance, have been demonstrated to inhibit seed germination and root growth (Nishida et al., 2005). By mediating competition between plant species, VOCs may allow to control weeds and thus enhance crop productivity through a more efficient acquisition of nutrients, water, and light (Puig et al., 2018).

Moreover, it was recently proposed that VOCs (i.e., isoprenoids) may work in synergy with other secondary metabolites (i.e., carotenoids) and hormones (i.e., cytokinins) which are all synthesized by the methyl erythritol phosphate (MEP) pathway to regulate senescence (Dani et al., 2016). Aging of plant tissues is controlled by changes in hormone levels (Woo et al., 2013) and may lead 
to uncontrolled accumulation of ROS following damage to cellular organs (i.e., membranes) (Stark, 2005) and other macromolecules (i.e., DNA) (Campisi and Vijg, 2009). Therefore, a sustained production of volatile isoprenoids may synergize with the biosynthesis of cytokinins and increase antioxidant activity at the foliar level. This could prevent cell degradation and death, thus prolonging the life span of leaves and flowers with a positive impact on the whole plant production process.

The trade-off between benefits and costs of VOC emission as stress relief compounds is not clear and difficult to assess. Experiments with transgenic plants suggest that the metabolic cost for emitting isoprene (the most abundant VOC released from leaves) outweighs benefits (Behnke et al., 2012).

\section{LIMITATIONS AND DRAWBACKS TO THE APPLICATION OF VOCS IN THE FIELD}

\section{Knowledge Boundaries}

Despite the demonstrated efficacy of VOCs in enhancing plant fitness and defense against stress in many controlled trials in the laboratory, their effectiveness to enhance plant defenses have been tested in the field only in a few cases (James and Price, 2004; Sugimoto et al., 2014). To date, VOCs are applied in agriculture solely for the "push-pull strategy", where the crop of interest is both intercropped with plant species that emit VOCs able to repel ("push") herbivores, and surrounded with plants emitting VOCs that simultaneously attract ("pull") herbivores away from the field (Stenberg et al., 2015; Picket and Khan, 2016) (Figure 1).

Why are VOCs not more intensively used in agriculture for integrated and eco-friendly plant protection? One reason could be that laboratory experiments demonstrating VOC efficacy have been performed with concentrations far higher than those achievable in open field. Trials to test the antimicrobial activity of VOCs are often performed in Petri dishes by applying pure liquid solution, without even quantifying the real VOC concentration present in the headspace over the course of the experiment. Moreover, while the high biodegradability of VOCs may minimize both their impact and the occurrence of long-term non-targeted effects, at the same time this limits VOC persistence and activity (Glare et al., 2012). Indeed, VOCs are often very reactive with the environment. Reports have demonstrated that VOCs disappear more rapidly in polluted environments where they can react with $\mathrm{NOx}, \mathrm{OH}$ - radicals, and ozone (McFrederick et al., 2009; Blande et al., 2014). Therefore, high reactivity of VOCs limits the distance they travel across the fields and their overall range of protection on crops. Reduction of VOC concentration in air may thus modulate their effect on insects, microbes, and plants. Finally, the very essence of VOCs (volatility) makes these compounds highly influenced by meteorological factors such as wind speed and direction, humidity and rain, and temperature, among others. It is also important to highlight that VOC emissions from leaves in the field can hardly be faithfully reproduced (Aksenov et al., 2014). In fact, complex blends rather than single VOCs are released by plants, and their biosynthesis is controlled by a network of different biochemical pathways (Dicke et al., 2009; Hare, 2010). In addition, the composition of VOC mixtures is subjected to strong plant genotypic and phenotypic plasticity and can vary according to the plant ontogenetic state (Bracho-Nunez et al., 2011) and environmental conditions (Brilli et al., 2016). Modern techniques of micro- and nano-encapsulation, which allow a more controlled release of synthetic blends that mimic the natural release of VOCs, are expected to improve VOC efficacy (Cabral Marques, 2010). Further efforts should be also made to decipher the perception mechanism of VOCs within plant tissues, since it is not yet clear how VOCs are perceived by plants. Indeed, molecules acting as VOC receptors have not been identified so far.

\section{Unexpected Results of VOC Application in the Field}

Some studies have reported other possible pitfalls of the application of VOCs in open fields that need to be carefully evaluated. For instance, the release of synthetic GLVs in the field synergistically affected isoprenoid emission from maize plants and unexpectedly increased herbivore damage without significantly attracting beneficial insects (von Mérey et al., 2011). Methanol emitted by wounded tobacco leaves was reported to enhance antibacterial defenses in neighboring non-wounded plants, but also facilitated the spreading of tobacco mosaic virus (TMV) (Dorokhov et al., 2012). In other cases, VOC phyto-toxicity was observed. For example, Neri et al. (2007) demonstrated that the concentration of trans2-hexenal required to exert the antimicrobial activity was phytotoxic for some fruits (i.e., apricot, peach, and nectarine), whereas plum fruits could be protected without damage to plant tissues. Importantly, application of Z-3-hexenyl acetate enhanced resistance of wheat plants against the pathogenic fungus $F$. graminearum while boosting the production of deoxynivalenol (DON), a dangerous mycotoxin for human health (Ameye et al., 2015).

\section{High "Price" to Pay for the Use of VOCs in Agriculture}

Technical limits and drawbacks may not have been the only constraints limiting the exploitation of VOCs in agricultural practices. High costs associated with the process of formulation, mass production, registration, and marketing of synthetic VOCs can make their sale price prohibitive, and initial investments unproductive (Blum et al., 2011). Depending on the screening procedures, 5-10 years may be required for research and development of effective and specific synthetic blends of VOCs (Glare et al., 2012). Elevated production costs and scalability limitations have inevitably slowed down the use of VOCs in agriculture (Miresmailli and Isman, 2014). Besides, the management of VOC-based products in the field may become expensive, and require 
specific technical skills that usually growers and retailers do not possess. Nevertheless, the current increasing demand for eco-friendly and sustainable solutions to protect crops and enhance their productivity, also due to increasingly stringent limitations on chemical pesticides (see the European legislation on Plant Protection Products), could attract future investments making the use of VOCs in agriculture competitive, especially in conditions where VOC application can be controlled more effectively and problems with synthetic chemicals can manifest (e.g., greenhouses).

\section{EXPLOITING VOCs IN FUTURE SUSTAINABLE AGRICULTURE: OUTLOOK}

\section{Reconsidering the Potential of VOC Applications in the Field}

Over the last years, domestication and man-driven crop selection have mainly focused on high yields. However, this has at the same time selected against VOCs and other secondary metabolites that, in unstressed plants, may compete with primary production and reduce yields (Aharoni et al., 2004; Köllner et al., 2008; Klee and Tieman, 2013). Coping with fast climate change and heavier biotic and abiotic stress conditions now requires rediscovery and exploitation of the arsenal of natural defenses that has allowed wild crops to thrive in hostile, unfarmed conditions. This could be attained by selecting plants with different VOC emission blends to be used for novel intercropping schemes, or by co-cultivating modern crops with wild varieties to exploit VOC-driven plant-to-plant signaling and priming (Duhamel and Vandenkoornhuyse, 2013). If properly intercropped, stresssensitive VOC-emitting plant species could act as "sentinel plants" and signal the occurrence of an imminent stressful situation to other neighboring crops of interest, which would be primed and become more resistant. Salt-stressed broad beans, wounded tobacco and pathogen-infected Arabidopsis have shown the ability to enhance resistance of neighboring unstressed plants through emission of VOCs (Dorokhov et al., 2012; Riedlmeier et al., 2017; Caparrotta et al., 2018). Alternatively, priming could be elicited by exposing plantlets to synthetic VOCs in confined environments (i.e., growth chamber or greenhouses) before transplanting in the field, thereby exploiting the long-term duration of the enhanced protection. Indeed, the time interval in which plants remain in the state of alertness (primed state) and therefore are more reactive to stress has demonstrated to last for days, weeks, or even be inherited through generations (Slaughter et al., 2012; Crisp et al., 2016). Modern crops could also be 'rewildered' (Palmgren et al., 2014) by directing breeding strategies toward the reintroduction of a more efficient capacity

\section{REFERENCES}

Aharoni, A., Giri, A. P., Verstappen, F. W. A., Bertea, C. M., Sevenier, R., Sun, Z., et al. (2004). Gain and loss of fruit flavor compounds produced to produce and emit VOCs lost during domestication, but of use in plant protection. Recently developed techniques of genetic engineering (i.e., gene editing) could also be employed to restore desired wild/old traits into the plants of agricultural interest (Tieman et al., 2017). This could allow either 'de novo' emission of inducible VOCs (e.g., isoprenoids, Schnee et al., 2006), or modification of the blend already biosynthesized in leaves, such as GLVs (Shiojiri et al., 2006). However, difficulties may arise when engineering the biosynthesis of VOCs due to unexpected pleiotropic effects (Rosenkranz and Schnitzler, 2013).

\section{Novel Technologies for Employing VOCs in Smart Agriculture Practices}

Nowadays, the availability of new analytical technologies such as high-resolution Proton Transfer Reaction "Timeof-Flight' mass spectrometry (PTR-TOF-MS) makes possible instantaneous and highly sensitive detection of the whole spectra of VOCs with high resolving power (Graus et al., 2010). This can provide in vivo a complete and highthroughput measurement of the entire blend of VOCs (the "volatome") emitted from plant leaves. Phenotyping the volatome could allow non-invasive screening of plant VOC profiles, assisting breeders in the selection of cultivars that successfully perform under changing environmental conditions and associated biotic stressors (Araus and Cairns, 2014). PTR-TOF-MS analysis could also enable a real-time diagnosis of the crop health status (Niederbacher et al., 2015), by monitoring in air the occurrence of specific VOC emissions (i.e., MeSA, sesquiterpenes) as stress biomarkers triggered by abiotic and biotic constraints (Karl et al., 2008; Chalal et al., 2015). Moreover, variations of VOC emission patterns over time can be used for precision agriculture purposes to monitor plant growth and development in the field. Likewise genomics and high throughput platforms for imaging and remote-sensing, real-time highly resolved VOC detection generate massive amount of data (Gandomi and Haider, 2015). This production of 'big data' requires computational analysis to extract patters and identify features useful for phenotyping (Singh et al., 2016). Implementation of machine learning tools to process information on VOC emissions along with environmental parameters collected in the field by multiple sensors will allow exploration of big data in order to measure plant performance and recognize early symptoms of stress.

\section{AUTHOR CONTRIBUTIONS}

FB and IB conceived and wrote the manuscript. FL critically revised the content and contributed to the writing.

by wild and cultivated strawberry species. Plant Cell 16, 3110-3131. doi: $10.1105 /$ tpc. 104.023895

Aksenov, A. A., Martini, X., Zhao, W., Stelinski, L. L., and Davis, C. E. (2014). Synthetic blends of volatile, phytopathogen-induced odorants can be used 
to manipulate vector behavior. Front. Ecol. Evol. 2:78. doi: 10.3389/ fevo.2014.00078

Ameye, M., Audenaert, K., De Zutter, N., Steppe, K., Van Meulebroek, L., Vanhaecke, L., et al. (2015). Priming of wheat with the green leaf volatile Z-3-hexenyl acetate enhances defense against Fusarium graminearum but boosts deoxynivalenol production. Plant Physiol. 167, 1671-1684. doi: 10.1104/ pp. 15.00107

Anderson, P. K., Cunningham, A. A., Patel, N. G., Morales, F. J., Epstein, P. R., and Daszak, P. (2004). Emerging infectious diseases of plants: pathogen pollution, climate change and agrotechnology drivers. Trends Ecol. Evol. 19, 535-544. doi: 10.1016/j.tree.2004.07.021

Araus, J. L., and Cairns, J. E. (2014). Field high-throughput phenotyping: the new crop breeding frontier. Trends Plant Sci. 19, 52-61. doi: 10.1016/j. tplants.2013.09.008

Arimura, G., Shiojiri, K., and Karban, R. (2010). Acquired immunity to herbivory and allelopathy caused by airborne plant emissions. Phytochemistry 71, 1642-1649. doi: 10.1016/j.phytochem.2010.06.021

Baker, R. H. A., Sansford, C. E., Jarvis, C. H., Cannon, R. J. C., MacLeod, A., and Walters, K. F. A. (2000). The role of climatic mapping in predicting the potential geographical distribution of non-indigenous pests under current and future climates. Agric. Ecosyst. Environ. 82, 57-71. doi: 10.1016/ S0167-8809(00)00216-4

Baldwin, I. T., Halitschke, R., Paschold, A., von Dahl, C. C., and Preston, C. A. (2006). Volatile signaling in plant-plant interactions: "talking trees" in the genomics era. Science 311, 812-815. doi: 10.1126/science.1118446

Behnke, K., Grote, R., Brüggemann, N., Zimmer, I., Zhou, G., Elobeid, M., et al. (2012). Isoprene emission-free poplars - a chance to reduce the impact from poplar plantations on the atmosphere. New Phytol. 194, 70-82. doi: 10.1111/j. 1469-8137.2011.03979.x

Bertini, L., Proietti, S., Focaracci, F., Sabatini, B., and Caruso, C. (2018). Epigenetic control of defense genes following MeJA-induced priming in rice (O. sativa). J. Plant Physiol. 228, 166-177. doi: 10.1016/j.jplph.2018.06.007

Blande, J. D., Holopainen, J. K., and Niinemets, U. (2014). Plant volatiles in a polluted atmosphere: stress response and signal degradation. Plant Cell Environ. 37, 1892-1904. doi: 10.1111/pce.12352

Blum, B., Nicot, P. C., Köhl, J., and Ruocco, M. (2011). "Identified difficulties and conditions for field success of biocontrol: 4. Socio-economic aspects: market analysis and outlook" in Classical and Augmentative Biological Control Against Diseases and Pests: Critical Status Analysis and Review of Factors Influencing Their Success. ed. P. Nicot, 58-61. ISBN 9789290672432.

Bracho-Nunez, A., Welter, S., Staudt, M., and Kesselmeier, J. (2011). Plantspecific volatile organic compound emission rates from young and mature leaves of Mediterranean vegetation. J. Geophys. Res. 116:D16304. doi: 10.1029/2010JD015521

Brilli, F., Gioli, B., Fares, S., Terenzio, Z., Zona, D., Gielen, B., et al. (2016). Rapid leaf development drives the seasonal pattern of volatile organic compound (VOC) fluxes in a 'coppiced' bioenergy poplar plantation. Plant Cell Environ. 39, 539-555. doi: 10.1111/pce.12638

Brilli, F., Ruuskanen, T. M., Schnitzhofer, R., Müller, M., Breitenlechner, M., Bittneret, V., et al. (2011). Detection of plant volatiles after leaf wounding and darkening by proton transfer reaction "Time-of-Flight" mass spectrometry (PTR-TOF). PLoS One 6:e20419. doi:10.1371/journal.pone.0020419

Cabral Marques, H. M. (2010). A review on cyclodextrin encapsulation of essential oils and volatiles. Flavour Fragr. J. 25, 313-326. doi: 10.1002/ffj.2019

Campisi, J., and Vijg, J. (2009). Does damage to DNAand othermacromolecules play a role in aging? If so, how? J. Gerontol. A Biol. Sci. Med. Sci. 64, 175-178. doi: 10.1093/gerona/gln065

Caparrotta, S., Boni, S., Taiti, C., Palm, E., Mancuso, S., and Pandolfi, C. (2018). Induction of priming by salt stress in neighboring plants. Environ. Exp. Bot. 147, 261-270. doi: 10.1016/j.envexpbot.2017.12.017

Chalal, M., Winkler, J. B., Gourrat, K., Trouvelot, S., Marielle, A., Schnitzler, J. P., et al. (2015). Sesquiterpene volatile organic compounds (VOCs) are markers of elicitation by sulfated laminarine in grape vine. Front. Plant Sci. 6:350. doi: $10.3389 /$ fpls.2015.00350

Cofer, T. M., Engelberth, M., and Engelberth, J. (2018). Green leaf volatiles protect maize (Zea mays) seedlings against damage from cold stress. Plant Cell Environ. 41, 1673-1682. doi: 10.1111/pce.13204
Conley, D. J., Paerl, H. W., Howarth, R. H., Boesch, D. F., Seitzinger, S. P., Havens, K. E., et al. (2009). Controlling eutrophication: nitrogen and phosphorus. Science 323, 1014-1015. doi: 10.1126/science.1167755

Conrath, U., Beckers, G. J., Langenbach, C. J., and Jaskiewicz, M. R. (2015). Priming for enhanced defense. Annu. Rev. Phytopathol. 53, 97-119. doi: 10.1146/annurev-phyto-080614-120132

Conrath, U., Pieterse, C. M., and Mauch-Mani, B. (2002). Priming in plantpathogen interactions. Trends Plant Sci. 7, 210-216. doi: 10.1016/ S1360-1385(02)02244-6

Crisp, P. A., Ganguly, D., Eichten, S. R., Borevitz, J. O., and Pogson, B. J. (2016). Reconsidering plant memory: intersections between stress recovery, RNA turnover, and epigenetics. Sci. Adv. 2:e1501340. doi: 10.1126/ sciadv. 1501340

Dani, K. G. S., Fineschi, S., Michelozzi, M., and Loreto, F. (2016). Do cytokinins, volatile isoprenoids and carotenoids synergically delay leaf senescence? Plant Cell Environ. 39, 1103-1111. doi: 10.1111/pce.12705

De Moraes, C. M., Lewis, W. J., Pare, P. W., Alborn, H. T., and Tumlinson, J. H. (1998). Herbivore-infested plants selectively attract parasitoids. Nature 393, 570-573. doi: 10.1038/31219

Dempsey, D. A., and Klessig, D. F. (2012). SOS-too many signals for systemic acquired resistance? Trends Plant Sci. 17, 538-545. doi: 10.1016/j. tplants.2012.05.011

Dicke, M., and Baldwin, I. T. (2010). The evolutionary context for herbivoreinduced plant volatiles: beyond the 'cry for help'. Trends Plant Sci. 15, 167-175. doi: 10.1016/j.tplants.2009.12.002

Dicke, M., van Loon, J. J. A., and Soler, R. (2009). Chemical complexity of volatiles from plants induced by multiple attack. Nat. Chem. Biol. 5, 317-324. doi: 10.1038/nchembio.169

Dorokhov, Y. L., Komarova, T. V., Petrunia, I. V., Frolova, O. Y., Pozdyshev, D. V., and Gleba, Y. Y. (2012). Airborne signals from a wounded leaf facilitate viral spreading and induce antibacterial resistance in neighboring plants. PLoS Pathog. 8:e1002640. doi: 10.1371/journal.ppat.1002640

Duhamel, M., and Vandenkoornhuyse, P. (2013). Sustainable agriculture: possible trajectories from mutualistic symbiosis and plant neodomestication. Trends Plant Sci. 18, 597-600. doi: 10.1016/j.tplants.2013.08.010

FAO (2017). The future of food and agriculture-Trends and challenges. Rome, Italy. ISBN 978-92-5-109551-5.

Fischer, N. H. (1986). "The function of mono and sesquiterpenes as plant germination and growth regulators" in The science of allelopathy. eds. A. Putnam and T. Chung-Shih (New York: Wiley-Interscience), 203-218.

Gandomi, A., and Haider, M. (2015). Beyond the hype: big data concepts, methods, and analytics. Int. J. Inf. Manag. 35, 137-144. doi: 10.1016/j. ijinfomgt.2014.10.007

Gardener, H. W., DornbosD. L. Jr., and Desjardins, A. E. (1990). Hexanal, trans-2-hexenal, and trans-2-nonenal inhibit soybean, Glycine max, seed germination. J. Agric. Food Chem. 38, 1316-1320. doi: 10.1021/jf00096a005

Glare, T., Caradus, J., Gelernter, W., Jackson, T., Keyhani, N., Köhl, J., et al. (2012). Have biopesticides come of age? Trends Biotechnol. 30, 250-258. doi: 10.1016/j.tibtech.2012.01.003

Grassini, P., Eskridge, K. M., and Cassman, K. G. (2013). Distinguishing between yield advances and yield plateaus in historical crop production trends. Nat. Commun. 4:2918. doi: 10.1038/ncomms3918

Graus, M., Müller, M., and Hansel, A. (2010). High resolution PTR-TOF: quantification and formula confirmation of VOC in real time. J. Am. Soc. Mass Spectrom. 21, 1037-1044. doi: 10.1016/j.jasms.2010.02.006

Guenther, A., Karl, T., Harley, P., Wiedinmyer, C., Palmer, P. I., and Geron, C. (2006). Estimates of global terrestrial isoprene emissions using MEGAN (model of emissions of gases and aerosols from nature). Atmos. Chem. Phys. 6, 3181-3210. doi: 10.5194/acp-6-3181-2006

Hare, J. D. (2010). Ontogeny and Season Constrain the Production of HerbivoreInducible Plant Volatiles in the Field. J. Chem. Ecol. 36, 1363-1374. doi: $10.1007 / \mathrm{s} 10886-010-9878-\mathrm{Z}$

Heil, M., and Kost, C. (2006). Priming of indirect defences. Ecol. Lett. 9, 813-817. doi: 10.1111/j.1461-0248.2006.00932.x

Heil, M., and Silva Bueno, J. C. (2007). Within-plant signaling by volatiles leads to induction and priming of an indirect plant defense in nature. Proc. Natl. Acad. Sci. USA 104, 5467-5472. doi: 10.1073/pnas.0610266104 
Hilker, M., Schwachtje, J., Baier, M., Balazadeh, S., Bäurle, I., Geiselhardt, S., et al. (2016). Priming and memory of stress responses in organisms lacking a nervous system. Biol. Rev. Camb. Philos. Soc. 91, 1118-1133. doi: 10.1111/ brv. 12215

IPCC (2014) in Climate change 2014: Synthesis report. Contribution of working groups I, II and III to the fifth assessment report of the intergovernmental panel on climate change. eds. R. K. Pachauri and L. A. Meyer (Geneva, Switzerland: IPCC), $151 \mathrm{pp}$.

James, D. G., and Price, T. S. (2004). Field-testing of methyl salicylate for recruitment and retention of beneficial insects in grapes and hops. J. Chem. Ecol. 30, 1613-1628. doi: 10.1023/B:JOEC.0000042072.18151.6f

Karl, T., Guenther, A., Turnipseed, A., Patton, E. G., and Jardine, K. (2008). Chemical sensing of plant stress at the ecosystem scale. Biogeosciences 5, 1287-1294. doi: 10.5194/bg-5-1287-2008

Kim, J., and Felton, G. W. (2013). Priming of antiherbivore defensive responses in plants. Insect Sci. 20, 273-285. doi: 10.1111/j.1744-7917.2012.01584.x

Klee, H. J., and Tieman, D. M. (2013). Genetic challenges of flavor improvement in tomato. Trends Genet. 29, 257-262. doi: 10.1016/j.tig.2012.12.003

Köberl, M., Schmidt, R., Ramadan, E. M., Bauer, R., and Berg, G. (2011). The microbiome of medicinal plants: diversity and importance for plant growth, quality and health. Front. Microbiol. 4:400. doi: 10.3389/fmicb.2013.00400

Köllner, T. G., Held, M., Lenk, C., Hiltpold, I., Turlings, T. C. J., Gershenzon, J., et al. (2008). A maize (E)- $\beta$-caryophyllene synthase implicated in indirect defense responses against herbivores is not expressed in most american maize varieties. Plant Cell 20, 482-494. doi: 10.1105/tpc.107.051672

Loreto, F., Csengele, B., Brilli, F., and Nogués, I. (2006). On the induction of volatile organic compound emissions by plants as consequence of wounding or fluctuations of light and temperature. Plant Cell Environ. 29, 1820-1828. doi: $10.1111 /$ j.1365-3040.2006.01561.x

Loreto, F., and Schnitzler, J. P. (2010). Abiotic stresses and induced BVOCs. Trends Plant Sci. 15, 154-166. doi: 10.1016/j.tplants.2009.12.006

Loreto, F., and Velikova, V. (2001). Isoprene produced by leaves protects the photosynthetic apparatus against ozone damage, quenches ozone products, and reduces lipid peroxidation of cellular membranes. Plant Physiol. 127, 1781-1787. doi: 10.1104/pp.010497

Luna-Diez, E. (2016). Using green vaccination to brighten the agronomic future. Outlooks on Pest Management 27, 136-140. doi: 10.1564/v27_jun_10

Marques, J. P. R., Amorim, L., Silva-Junior, G. J., Spósito, M. B., and Appezzatoda Gloria, B. (2014). Structural and biochemical characteristics of citrus flowers associated with defense against a fungal pathogen. AoB Plants 7:plu090. doi: 10.1093/aobpla/plu090

Martinez-Medina, A., Flors, V., Heil, M., Mauch-Mani, B., Pieterse, C. M. J., Pozo, M. J., et al. (2016). Recognizing plant defense priming. Trends Plant Sci. 21, 818-822. doi: 10.1016/j.tplants.2016.07.009

Mauch-Mani, B., Baccelli, I., Luna, E., and Flors, V. (2017). Defense priming: an adaptive part of induced resistance. Annu. Rev. Plant Biol. 68, 485-512. doi: 10.1146/annurev-arplant-042916-041132

McFrederick, S. Q., Fuentes, J. D., Roulston, T., Kathilankal, J. C., and Lerdau, M. (2009). Effects of air pollution on biogenic volatiles and ecological interactions. Oecologia 160, 411-420. doi: 10.1007/s00442-009-1318-9

Miresmailli, S., and Isman, M. B. (2014). Botanical insecticides inspired by plant-herbivore chemical interactions. Trends Plant Sci. 19, 29-35. doi: 10.1016/j.tplants.2013.10.002

Nemecek-Marshall, M., Macdonald, R. C., Franzen, F. J., Wojciechowski, C. L., and Fall, R. (1995). Methanol emission from leaves - enzymatic detection of gas-phase methanol and relation of methanol fluxes to stomatal conductance and leaf development. Plant Physiol. 108, 1359-1368. doi: $10.1104 /$ pp.108.4.1359

Neri, F., Mari, M., Brigati, S., and Bertolini, P. (2007). Fungicidal activity of plant volatile compounds for controlling Monilinia laxa in stone fruit. Plant Dis. 91, 30-35. doi: 10.1094/PD-91-0030

Niederbacher, B., Winkler, J. B., and Schnitzler, J. P. (2015). Volatile organic compounds as non-invasive markers for plant phenotyping. J. Exp. Bot. 66, 5403-5416. doi: 10.1093/jxb/erv219

Nishida, N., Tamotsu, S., Nagata, N., Saito, C., and Sakai, A. (2005). Allelopathic effects of volatile monoterpenoids produced by Salvia leucophylla: inhibition of cell proliferation and DNA synthesis in the root apical meristem of
Brassica campestris seedlings. J. Chem. Ecol. 31, 1187-1203. doi: 10.1007/ s10886-005-4256-y

Palmgren, M. G., Edenbrandt, K., Vedel, S. E., Andersen, M. M., Landes, X., Østerberg, J. T., et al. (2014). Are we ready for back-to-nature crop breeding? Trends Plant Sci. 20, 155-164. doi: 10.1016/j.tplants.2014.11.003

Peñuelas, J., Poulter, B., Sardans, J., Ciais, P., van der Velde, M., Bopp, L., et al. (2013). Human-induced nitrogen-phosphorus imbalances alter natural and managed ecosystems across the globe. Nat. Commun. 4:2934. doi: 10.1038/ ncomms3934

Picket, J. A., and Khan, Z. R. (2016). Plant volatile-mediated signalling and its application in agriculture: successes and challenges. New Phytol. 212, 856-870. doi: 10.1111/nph.14274

Puig, C. G., Gonçalves, R. F., Valentão, P., Andrade, P. B., Reigosa, M. J., and Pedrol, N. (2018). The consistency between phytotoxic effects and the dynamics of allelochemicals release from eucalyptus globulus leaves used as bioherbicide green manure. J. Chem. Ecol. 44, 658-670. doi: 10.1007/ s10886-018-0983-8

Quintana-Rodriguez, E., Rivera-Macias, L. E., Adame-Alvarez, R. M., Torres, J. M., and Heil, M. (2018). Shared weapons in fungus-fungus and fungusplant interactions? Volatile organic compounds of plant or fungal origin exert direct antifungal activity in vitro. Fungal Ecol. 33, 115-121. doi: 10.1016/j.funeco.2018.02.005

Riedlmeier, M., Ghirardo, A., Wenig, M., Knappe, C., Koch, K., Georgii, E., et al. (2017). Monoterpenes support systemic acquired resistance within and between plants. Plant Cell 29, 1440-1459. doi: 10.1105/tpc.16.00898

Rosenkranz, M., and Schnitzler, J. P. (2013). "Genetic engineering of BVOC emissions from trees" in Biology, controls and models of tree volatile organic compound emissions. Tree physiology. eds. Ü. Niinemets and R. Monson, vol. 5 (Dordrecht: Springer).

Schnee, C., Köllner, T. G., Held, M., Turlings, T. C. J., Gershenzon, J., and Degenhardt, J. (2006). The products of a single maize sesquiterpene synthase form a volatile defense signal that attracts natural enemies of maize herbivores. Proc. Natl. Acad. Sci. USA 103, 1129-1134. doi: 10.1073/ pnas.0508027103

Sekine, T., Sugano, M., Azizi, M., and Fujii, Y. (2007). Antifungal effects of volatile compounds from Black zira (Bunium persicum) and other spices and herbs. J. Chem. Ecol. 33, 2123-2132. doi: 10.1007/ s10886-007-9374-2

Shiojiri, K., Kishimoto, K., Ozawa, R., Kugimiya, S., Urashimo, S., Arimura, G., et al. (2006). Changing green leaf volatile biosynthesis in plants: an approach for improving plant resistance against both herbivores and pathogens. Proc. Natl. Acad. Sci. USA 103, 16672-16676. doi: 10.1073/pnas.0607780103

Simas, D. L. R., de Amorim, S. H. B. M., Goulart, F. R. V., Alviano, C. S., Alviano, D. S., and da Silva, A. J. R. (2017). Citrus species essential oils and their components can inhibit orstimulate fungal growth in fruit. Ind. Crop. Prod. 98, 108-115. doi: 10.1016/j.indcrop.2017.01.026

Singh, A., Ganapathysubramanian, B., Singh, A. K., and Sarkar, S. (2016). Machine learning for high-throughput stress phenotyping in plants. Trends Plant Sci. 21, 110-124. doi: 10.1016/j.tplants.2015.10.015

Slaughter, A., Daniel, X., Flors, V., Luna, E., Hohn, B., and Mauch-Mani, B. (2012). Descendants of primed Arabidopsis plants exhibit resistance to biotic stress. Plant Physiol. 158, 835-843. doi: 10.1104/pp.111.191593

Stark, G. (2005). Functional consequences of oxidative membrane damage. J. Membr. Biol. 205, 1-16. doi: 10.1007/s00232-005-0753-8

Stenberg, J. A., Heil, M., Åhman, I., and Björkman, C. (2015). Optimizing crops for biocontrol of pests and disease. Trends Plant Sci. 20, 698-712. doi: 10.1016/j.tplants.201508.007

Sugimoto, K., Matsui, K., Iijima, Y., Akakabe, Y., Muramoto, S., Ozawa, R., et al. (2014). Intake and transformation to a glycoside of (Z)-3-hexenol from infested neighbors reveals a mode of plant odor reception and defense. Proc. Natl. Acad. Sci. USA 111, 7144-7149. doi: 10.1073/pnas.1320660111

Tieman, D., Zhu, G., Resende, M., Lin, T., Nguyen, C., Bies, D., et al. (2017). A chemical genetic roadmap to improved tomato flavor. Science 355 391-394. doi: 10.1126/science.aal1556

van Hulten, M., Pelser, M., van Loon, L. C., Pieterse, C. M., and Ton, J. (2006). Costs and benefits of priming for defense in Arabidopsis. Proc. Natl. Acad. Sci. USA 103, 5602-5607. doi: 10.1073/pnas.0510213103 
Velikova, V., Várkonyi, Z., Szabó, M., Maslenkova, L., Nogues, I., Kovács, L., et al. (2011). Increased thermostability of thylakoid membranes in isopreneemitting leaves probed with three biophysical techniques. Plant Physiol. 157, 905-916. doi: 10.1104/pp.111.182519

von Mérey, M., Veyrata, N., Mahuku, G., Lopez Valdez, R., Turlings, T. C. J., and D'Alessandro, M. (2011). Dispensing synthetic green leaf volatiles in maize fields increases the release of sesquiterpenes by the plants, but has little effect on the attraction of pest and beneficial insects. Phytochemistry 72, 1838-1847. doi: 10.1016/j.phytochem.2011.04.022

Woo, H. R., Kim, H. J., Nam, H. G., and Lim, P. O. (2013). Plant leaf senescence and death-regulation by multiple layers of control and implications for aging in general. J. Cell Sci. 126, 4823-4833. doi: 10.1242/jcs.109116

Yi, H. S., Heil, M., Adame-Alvarez, R. M., Ballhorn, D. J., and Ryu, C. M. (2009). Airborne induction and priming of plant defenses against a bacterial pathogen. Plant Physiol. 151, 2152-2161. doi: 10.1104/pp.109.144782
Zhao, M., and Running, S. W. (2009). Drought-induced reduction in global terrestrial net primary production from 2000 through 2009. Science 329, 940-943. doi: 10.1126/science.1192666

Conflict of Interest Statement: The authors declare that the research was conducted in the absence of any commercial or financial relationships that could be construed as a potential conflict of interest.

Copyright (C) 2019 Brilli, Loreto and Baccelli. This is an open-access article distributed under the terms of the Creative Commons Attribution License (CC $B Y)$. The use, distribution or reproduction in other forums is permitted, provided the original author(s) and the copyright owner(s) are credited and that the original publication in this journal is cited, in accordance with accepted academic practice. No use, distribution or reproduction is permitted which does not comply with these terms. 